\title{
ULTRAVÉKONY FÉMÜVEG SZALAG MECHANIKAI TULAJDONSÁGAINAK JELLEMZÉSE
}

\section{MECHANICAL CHARACTERIZATION OF ULTRATHIN SHEET METALLIC GLASS}

\author{
Dobosi Zoltán ${ }^{1}$, Béres Gábor ${ }^{* 1}$ \\ ${ }^{1}$ Innovatív Jármüvek és Anyagok Tanszék, GAMF Müszaki és Informatikai Kar, Neumann János Egyetem, \\ Magyarország \\ https://doi.org/10.47833/2021.1.ENG.012
}

\section{Kulcsszavak:}

amorf fém

rugalmassági modulus

Poisson-tényező

\section{Keywords:}

amorphous metal

elasticity moduli

Poisson-ratio

\section{Cikktörténet:}

Beérkezett 2021. március 10

Átdolgozva 2021. április 15

Elfogadva 2021. április 20

\section{Összefoglalás}

Ez a tanulmány egy ultravékony, vasalapú fémüveg szalag mechanikai tulajdonságait tárgyalja. Szabványos mérési eljárásokkal mértük a fémüveg szalagból kimunkált próbatestek keménységét és egytengelyü húzással szembeni ellenállsását, illetve meghatároztuk az ebben az állapotban mérhetö alakváltozási jellemzőket. A vizsgált minták kimunkálása lézersugaras vágással történt, amelyhez az optimális paraméter beállításokat a vágási zóna környezetében mért keménységlefutások tükrében és a vágott szél felületi minőségének megfigyelésével állitottuk be. Megfigyeltük továbbá a mechanikai tulajdonságok szórását is, amely nagy hangsúlyt kap a fémüveg szalagok terheléses vizsgálatinál. Mérésekkel és számításokkal definiáltuk a rugalmassági modulus és a Poisson-tényező értékeit és azok egyenértékü alakváltozás függését, két különböző keresztfej elmozdulási sebesség mellett. E két anyagjellemző az alakváltozás függvényében figyelemre méltó változásokat, viszont a vizsgált alakváltozási-sebességek tartományában elhanyagolható alakváltozás-sebesség érzékenységet mutatott.

\section{Abstract}

This study focuses on the mechanical properties of an iron-based ultrathin sheet metallic glass. Standard mechanical tests were performed to investigate the stress and strain reactions of the applied material in uni-axial tension. The tensile specimens were cut by laser-beam technology, to which the cutting parameters' optimization is also discussed in this paper. The effect of the laser beam parameters were investigated by microscopic and microhardness tests. Our results show that mechanical properties have significant deviations due to the special microstructure of this material. Besides, both the Poisson-ratio and the elasticity moduli presented remarkable evolution in the function of the tensile strain, but there was no noticeable change with the strain-rate increase. The deviation of the Poisson-ratio

Kapcsolattartó szerző: Béres Gábor. Tel.: +36 304326711

E-mail cím: beres.gabor@gamf.uni-neumann.hu 
was successfully reduced furthermore by a simple mathematical transformation of the strain values.

\section{Bevezetés}

Manapság az elektronikai innováció kapcsán találkozhatunk a fémüveg, vagy másnéven amorf fém kifejezéssel. Ezek olyan fémes anyagok, amelyek szerkezetében teljesmértékű rendezetlenség figyelhető meg, fizikai tulajdonságaik fémes jellegüek, de a fémekhez képest mégis sok eltérést mutatnak. Korlátot szab ezen anyagok felhasználásában azok kis keresztmetszetben történő előállíthatósága. Mivel azonban az elektronikai ipar a miniatürizálás felé halad, és az amorf fémek rendkívül jó lágymágneses tulajdonságokkal rendelkeznek, így azok kedvelt alapanyagnak minősülnek. Elsősorban, a vas alapú fémüvegeknél figyelhető meg ez a kedvező tulajdonság.

A kutatás alapját, a METGLAS fantázianevű, Fe90Si8B2 (atom\%-ban megadott) kémiai összetételű és átlagosan mindössze $0,024 \mathrm{~mm}$ vastagságú lemezanyag vizsgálatai alkották. Mivel az ilyen típusú anyagok lézersugaras megmunkálhatóságáról, illetve azok mechanikai terhelése során mutatott hossz és keresztirányú alakváltozási hajlamáról általában csak korlátozott mértékben áll információ a rendelkezésünkre, így a fö cél a lézersugaras vágásnak a mechanikai tulajdonságokat befolyásoló hatásának és a rugalmas anyagparamétereknek (a rugalmassági modulusnak és a Poisson-tényezőnek) a pontosabb megismerése volt.

A kutatás első felét a próbatest kimunkálási módok vizsgálata alkotta, mivel a METGLAS anyag, annak fokozott rideg viselkedése révén, mechanikai-vágási technológiákkal csak rossz minőségben munkálható meg. Ebben a témában a lézersugaras vágási technológiát választottuk. Szükség volt az ideális vágási, technológia paraméterek meghatározására, ugyanis ez az anyag meglehetősen érzékeny az azt érő hőhatásokra. A vágási hő hatását mikroszkópi, valamint keménységmérési eljárások során vizsgáltuk. A próbatestek előállítását követően egytengelyű szakítóvizsgálatoknak vetettük alá a fémüveg szalagot. Az alakváltozás mérésekhez érintésmentes nyúlásmérő rendszert alkalmaztunk, amely segítségével a szalag szakítószilárdsága mellett meghatározásra kerültek a különböző alakváltozási mérőszámok is, mint a rugalmassági modulus és a Poisson-tényező.

\section{A vizsgált anyag}

A fémüvegek, avagy amorf fémek olyan ötvözetek, melyeket fémes alkotók építenek fel, azonban mikroszerkezetük a megszokott kristályos szerkezettel ellentétben amorf. Összetételükböl adódóan rendelkeznek a fémekre jellemző fizikai tulajdonságokkal, ellenben mikroszkópi szerkezetük következtében egyéb jelentős eltérések tapasztalhatók. A kristályos és az amorf anyagok mikroszerkezetét, és egyben azok különbözőségét sematikusan szemlélteti az 1. ábra [1].
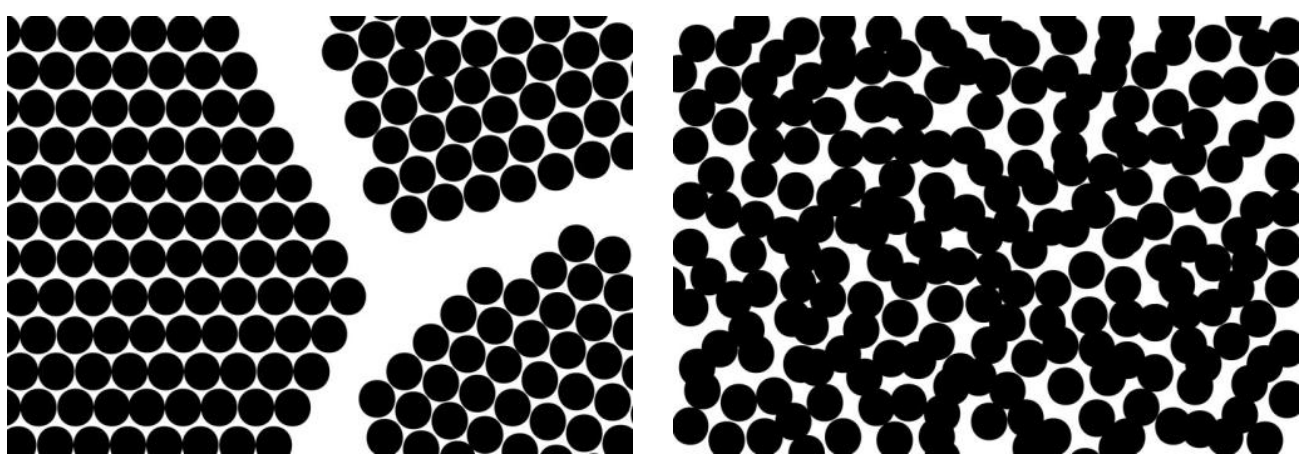

1.ábra. Kristályos (bal-) és amorf (jobb oldal) anyag mikroszerkezetének sematikus vázlata [4]

Ahhoz, hogy az amorf szerkezet ki tudjon alakulni, a kristályosodási folyamatot gátolni, mi több azt megakadályozni szükséges. Ez rendkívül gyors hűtés eredményeként érhető el, meghatározott kémiai összetételek esetében, ugyanis mint a legtöbb átalakulási folyamathoz, a kristályosodáshoz is idő szükséges. Amennyiben a hütési sebességgel átlépjük az anyagra, ötvözetre jellemző 
kristálycsíra képződési határértéket, nem lesz elegendő idő a kristálycsíra képződéshez és a rendszer úgymond befagy az amorf szerkezeti állapotába. Ilyen extrém nagy hütési sebesség elérése csak korlátozott összetételü ötvözetek esetén érhető el. Például, a jelenleg elérhető legnagyobb hütési sebesség mellett sem lehetséges az amorf szerkezet elérése tiszta fémek esetén. Előállításukhoz tehát két fő tényező szükséges: kellően nagy hütési sebesség elérése (amely egyben elöre vetíti a rendkívül kis előállítható szelvénymérteket), valamint relatív lassú kristályképződési sebesség [1].

A fémüvegek mechanikai tulajdonságaikat tekintve meglehetősen eltérő adatok tapasztalhatók. Jelentős eltérések alapvetően a szokatlan szerkezetböl és a kis lemezvastagságokból adódnak. Mivel az amorf fémek nem rendelkeznek a kristályos fémekre jellemző alakváltozási síkokkal, irányokkal szakítószilárdságuk kimagasló meghaladhatják az $1200 \mathrm{MPa}$ értéket is. Ugyanakkor ezen anyagok rendkívül ridegek. Folyáshatáruk és szakítószilárdságuk közel esik egymáshoz, sokszor el sem különíthetök és mindössze 1,0 - 2,5\% alakváltozásra képesek általában [1, 2, 3, 4].

\section{Próbatest kimunkálás}

A próbatestek előállitásához szükség volt a megfelelő vágási technológia megtalálására. Kísérleteink alapján, erre a feladatra a lézersugaras vágás, ezen belül is az impulzuslézerrel történő vágás bizonyult megfelelőnek. Az általunk alkalmazott Coherent Monaco típusú ultrarövid impulzus idejü, dióda gerjesztésű szál lézert alapvetően felületkezelésekre használják, azonban ilyen kis vastagság esetén alkalmas vágásra is $[1,3]$. A legkisebb mértékü höhatás ezzel az eljárással volt biztosítható. A próbavágásokat több paraméter alkalmazásával végeztük el úgy, hogy a különbözö paraméterekkel négyzetes kis mintákat vágtunk a 2. ábrának megfelelően.

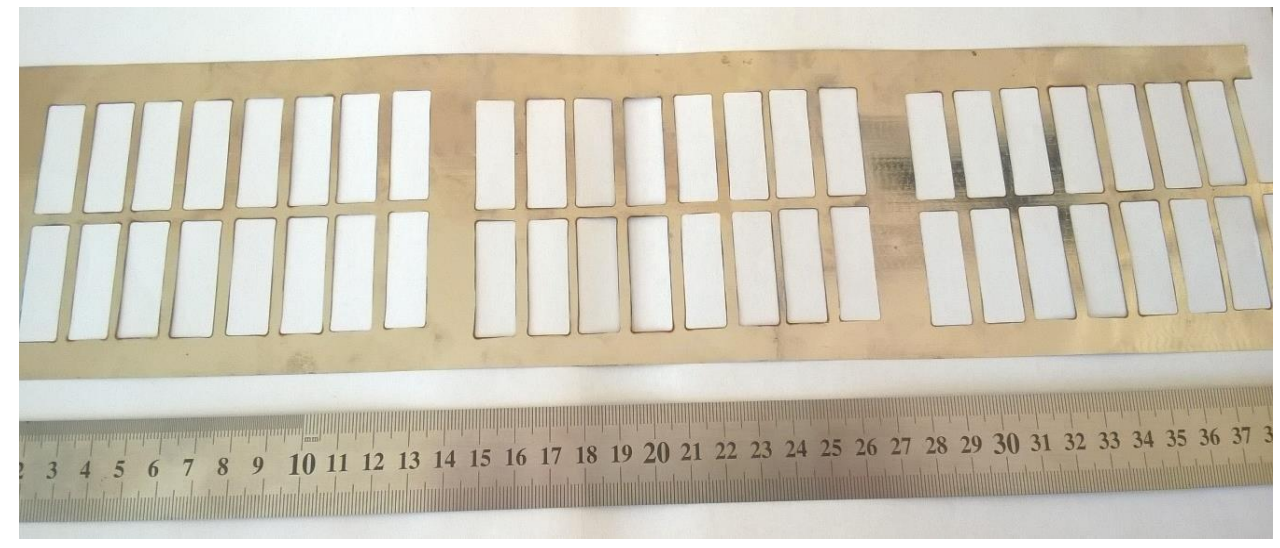

\section{2.ábra. Lézersugaras vágással megmunkált fémüveg szalag egy részlete, mintavétel}

A próbavágásokat 1050-szeres kontúr-körül járás és 277 femtoszekundumos impulzushossz mellett végeztük, rendre $42 \%, 40 \%$ és $38 \%$ teljesítménnyel, illetve $25 \mathrm{~m} / \mathrm{s}, 28 \mathrm{~m} / \mathrm{s}, 30 \mathrm{~m} / \mathrm{s}$ és $38 \mathrm{~m} / \mathrm{s}$ pásztázási sebességgel. A kimunkált mintadarabok vágott felületét, illetve hőtorzulását mikroszkópi, illetve keménységmérési eljárással vizsgáltuk.

\section{A vágott él geometriai- és keménységvizsgálata}

A vágott felületek élgeometriáját rugós mintatartó készülékbe fogva, Zeiss Imager M2m típusú fénymikroszkóp segítségével vizsgáltuk. Ezzel a folyamattal egybekötve megállapításra került a vágás utáni lemezvastagság is, amelyböl következtetni tudtunk az él deformációjára. Az egyes beállítások mellett kapott vágott él minőséget mutatja a 3. ábra.

A 3. ábrán látható, hogy a kiinduló $0,024 \mathrm{~mm}$ lemezvastagsághoz képest, a beállított teljesítménytöl függetlenül a legkisebb pásztázási sebesség $(25 \mathrm{~m} / \mathrm{s})$ okozta a legszembetünőbb torzulást és vastagságcsökkenést a vágott keresztmetszetben. A többi esetben a kiinduló vastagság közelében maradt a szalag normál irányú mérete. Ugyanakkor, a nagyobb teljesítmény, valamint kisebb pásztázási sebesség kombinációja egyenetlen, szakadozott felületet is eredményezett. 
A höhatás okozta változásokat mikro-Vickers eljárás segítségével is vizsgáltuk Wilson Wolpert 401 MVD típusú berendezéssel. A próbamérések eredményeként és a szabvány előirásait követve a 12 másodperces terhelési idő és a 0,98 $\mathrm{N}$ terhelő erő alkalmazása bizonyult a legmegfelelőbbnek, amely értékelhető eredményre (megfelelő lenyomat geometriára) vezetett, még ilyen kis lemezvastagságok esetén is [5].
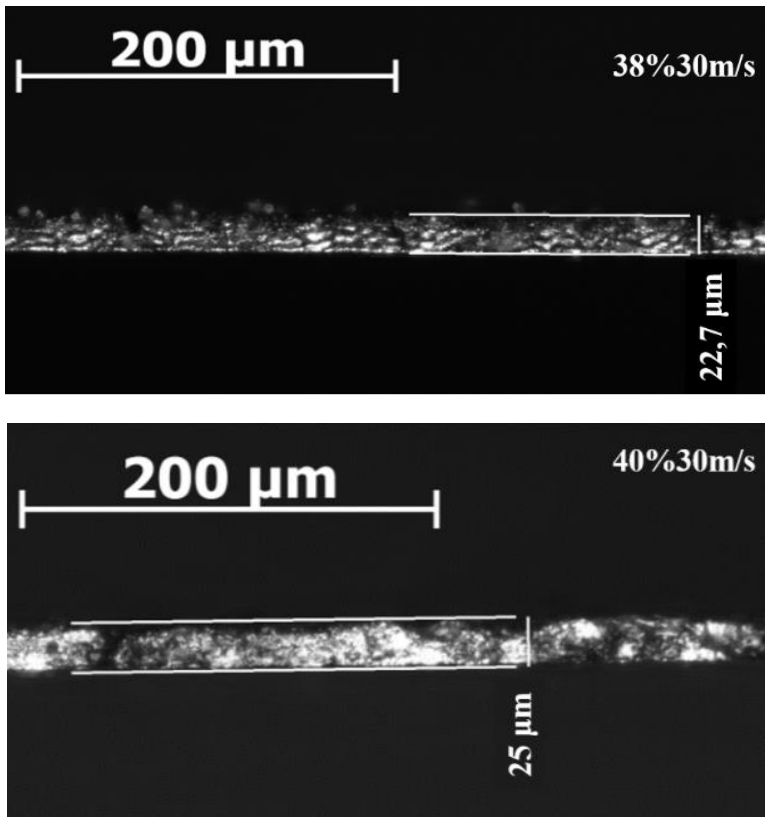
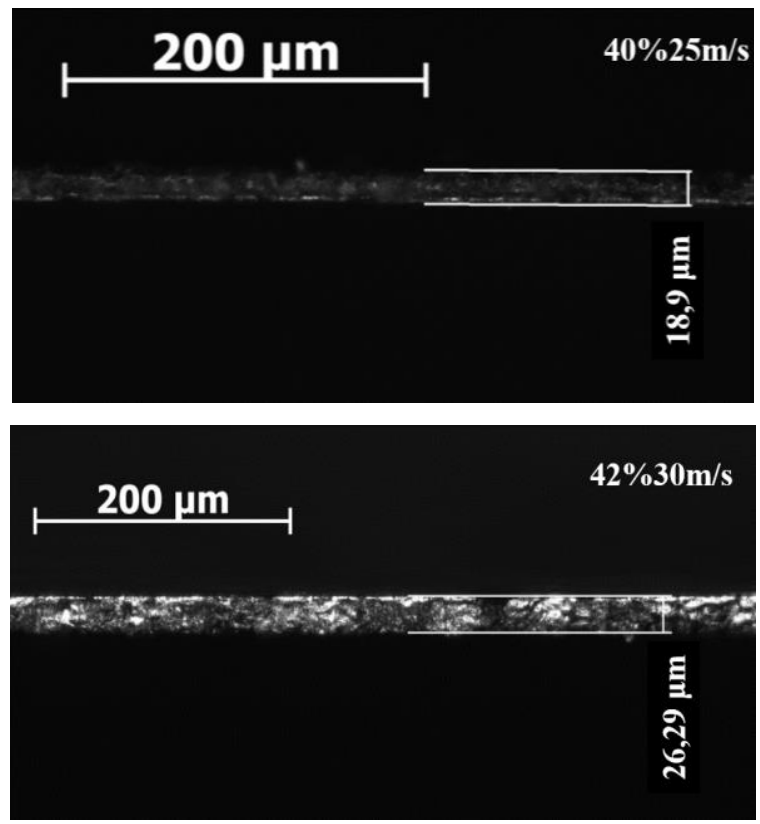

3.ábra. Négy különböző paraméterrel vágott mintadarab keresztmetszetének mikroszkópi képei

A méréseket a vágott éltől kiindulva, a felület belseje felé haladva egyenletes léptékenként hajtottuk végre. A kapott keménység traverzeket, az átlagos értékeket feltüntetve a különbözö vágási paraméterek mellett, a 4. ábra szemlélteti.

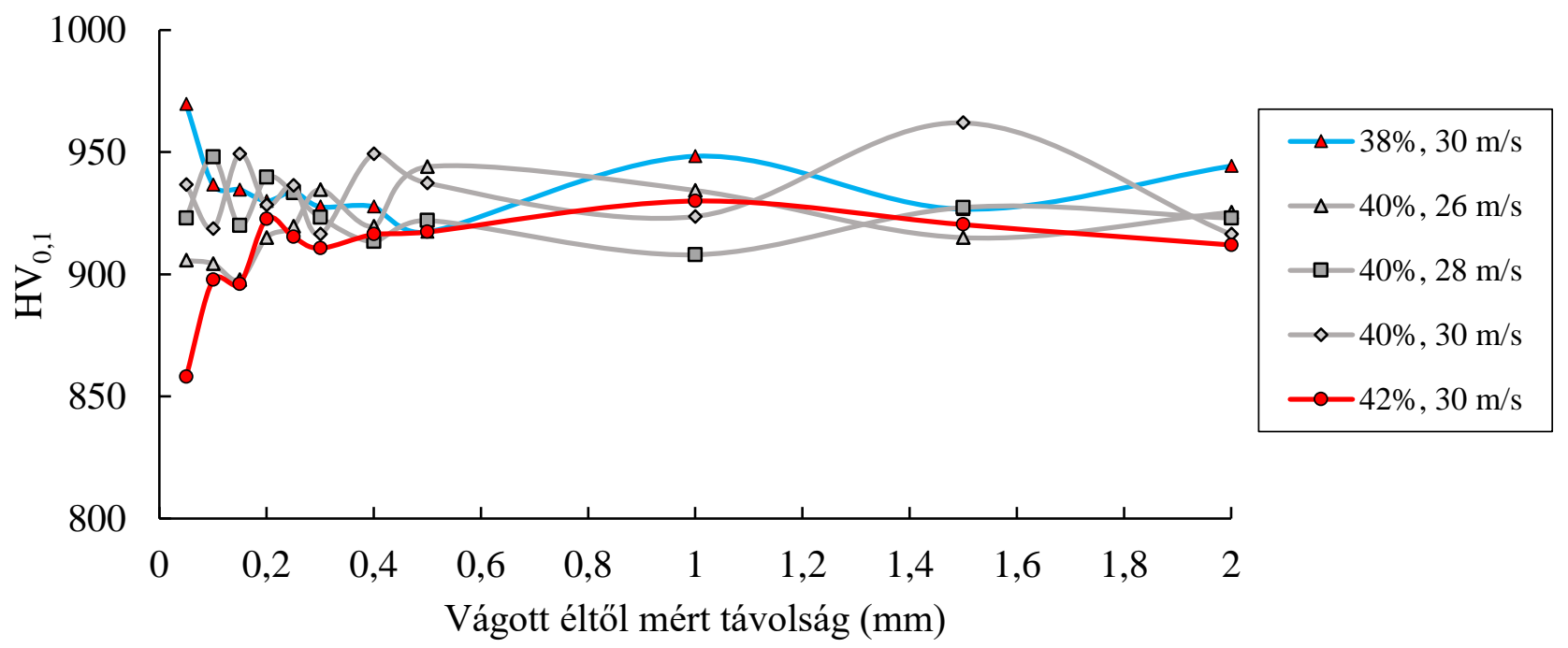

\section{4.ábra. A keménységlefutások összesitett eredményei}

A 4. ábra alapján a vágott él környezetében jelentős változások mutatkoznak a keménységi értékekben, ahogyan a vágási paraméterek változnak. A legnagyobb mértékű keménységcsökkenés a legnagyobb teljesítmény mellett tapasztalható, a legkisebb teljesítmény pedig enyhén pozitív irányban módosította a keménységet. Az értékek változása kb. 0,5 mm távolságig érzékelhető a vágott éltöl, majd a keménység közel állandó értéken marad minden paraméter esetében, amely érték megfelel az alapanyag átlagos keménységének (900 .. $\left.950 \mathrm{HV}_{0,1}\right)$. 
A mikroszkópi vizsgálatok és a keménységmérések alapján a szakítópróbatestek kimunkálását $40 \%$ teljesítmény és $30 \mathrm{~m} / \mathrm{s}$ pásztázási sebesség mellett végeztük.

\section{Szakítóvizsgálatok eredményei}

A szakítóvizsgálatokat érintésmentes nyúlásmérő rendszerrel (AVE Video Extensometer) ellátott Instron 4482 típusú szakítógéppel végeztük, háromszoros ismétlési gyakorisággal, ékes rendszerü befogókkal megszorított, szabványos $A_{80}$-as lemezpróbatesteken, szobahőmérsékleten, állandó keresztfej elmozdulási sebesség mellett [6]. A méréseknél $4 \mathrm{~mm} /$ perc és $0,4 \mathrm{~mm} /$ perc keresztfej elmozdulási sebességeket alkalmaztunk. A vizsgálatok eredményei láthatók az 5 . ábrán. Méréseink alapján, ebben a sebességtartományban számottevő különbség nem tapasztalható az anyag viselkedésében, mindkét terhelési sebességnél hasonló erő-út diagramok figyelhetők meg.

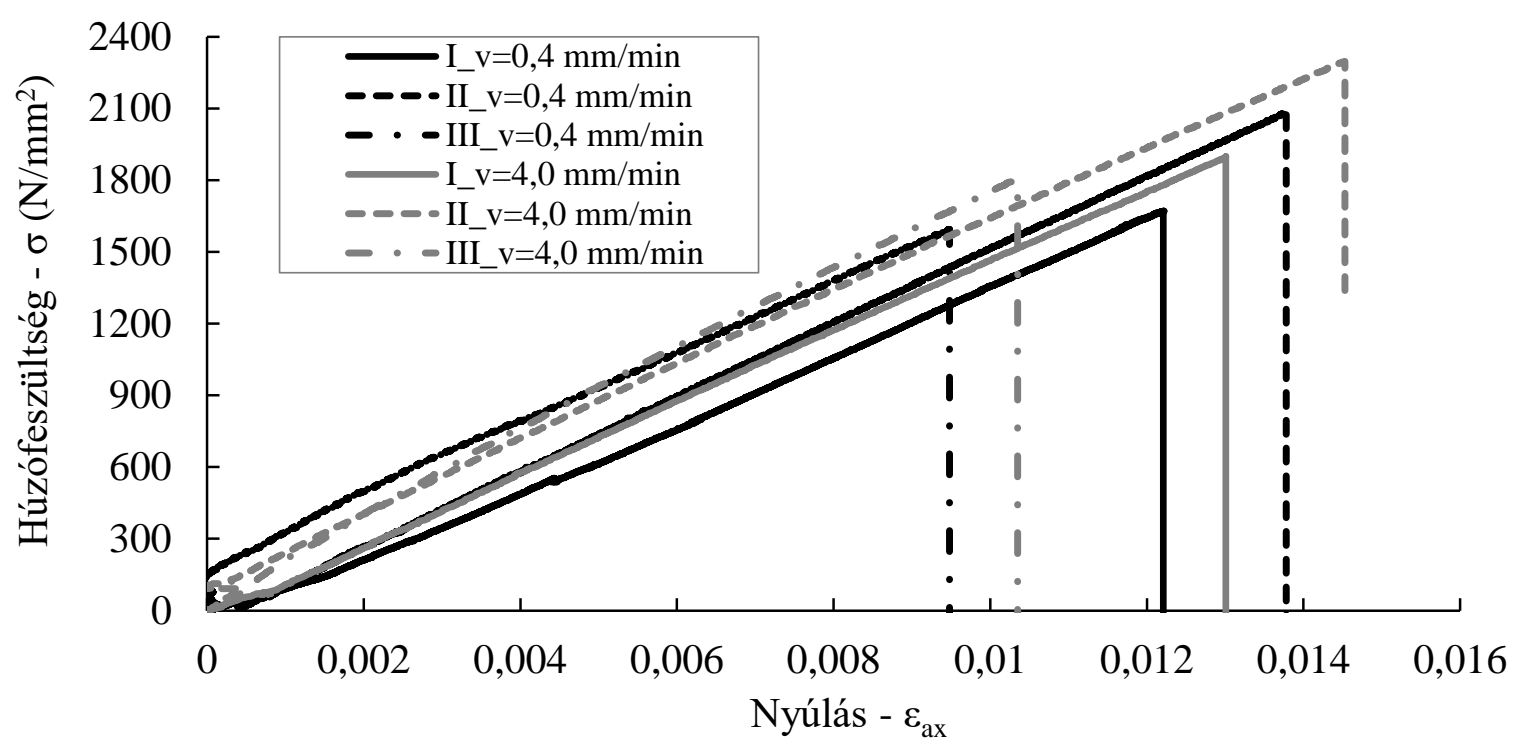

5.ábra. $4 \mathrm{~mm} /$ perc keresztfej elmozdulási sebesség mellett felvett próbatestek szakitódiagrammjai

A vizsgált lemezanyag rendkívül magas, több mint $1800 \mathrm{MPa}$ szakítószilárdsággal rendelkezik, amelyhez mindössze 0,015 nyúlás érték tartozik maximálisan. Egyik diagrammon sem figyelhető meg folyási, vagy képlékeny alakváltozási szakasz. A próbatestek a rugalmas alakváltozás tartományában szakadtak.

Az anyagra jellemző rugalmassági modulust 100 1/s mintavételi gyakoriság mellett rögzítettük a nyúlás függvényében. Az alakváltozások kezdetekor a modulus értéke meghaladja az acélokra jellemző $210 \mathrm{GPa}$ értéket, majd folyamatos csökkenés mellett - amely csökkenés a kezdeti szakaszban a legintenzívebb - felveszi a szakirodalmakban, a vas-alapú fémüvegekre szereplö 150 GPa körüli értéket. A rugalmassági modulus változásának egy jellemző képét a 6 . ábra szemlélteti. 


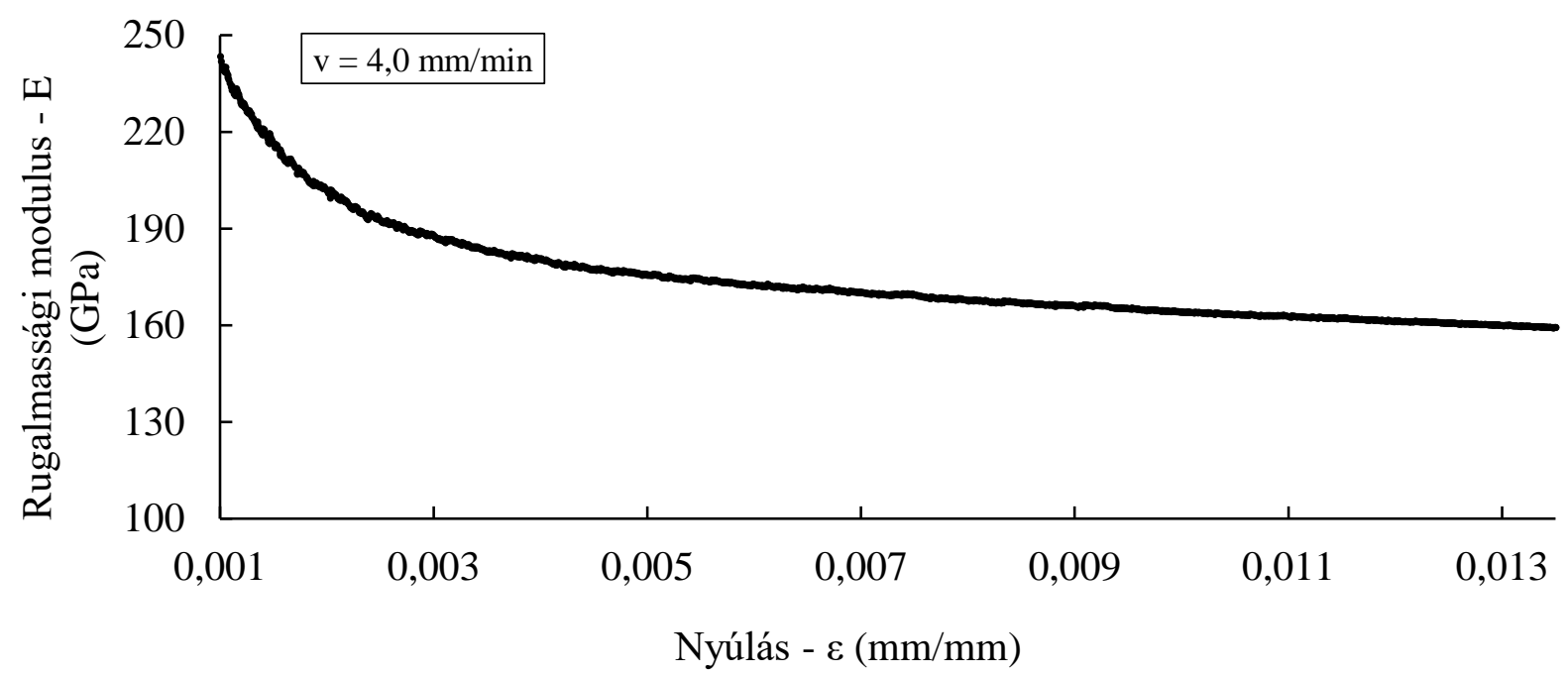

6. ábra. A rugalmassági modulus változása a nyúlás függvényében

Az anyagra jellemző Poisson-tényező (v) változása az alakváltozás függvényében a 7. ábrán követhető nyomon. Az alakváltozás kezdetén nagy kilengések tapasztalhatók, amelyek a nyúlás növekedésével folyamatosan csökkennek. A kezdeti szakaszhoz tartozó, rendkívül kis alakváltozások mérésének nehézségét tükrözi, hogy a mért adatok a 0.005 nyúlás értékig nagy szórást mutattak. Hasonló, kezdeti kiugró érték volt a rugalmassági modulus tekintetében is megfigyelhető a 6. ábrán.

Egy esetben a nagy kiugrások nem is produkáltak értelmezhető Poisson-tényező értéket. $A$ kilengések elsimítása érdekében, a kereszt irányú alakváltozásokat egyenesekkel közelítettük a hosszirányú alakváltozások függvényében (1. összefüggés). Így, a Poisson-tényezőt számítással is, egy egyenes egyenletének konstans együtthatóival meghatároztuk (2. összefüggés), amely mindenben egyezően illeszkedett a nagyobb alakváltozásoknál mért v értékekre, és minimalizálta a szórásokat a számolt értékek tekintetében. Mivel az $\varepsilon_{1}-\varepsilon_{2}$ koordináta rendszerben a mérési adatsorok az origóból indulnak, így a $\mathrm{C}_{2}$ együttható értéke egységesen zérus volt. $\mathrm{A}$ diagramon szereplő mintára vonatkozó, számolt Poisson-tényezőt egyenes vonal szemlélteti a 7. ábrán.

$$
\begin{gathered}
\varepsilon_{a x}=C_{1} * \varepsilon_{t r}+C_{2} \\
v=\frac{\varepsilon_{a x}}{C_{1} * \varepsilon_{a x}}
\end{gathered}
$$

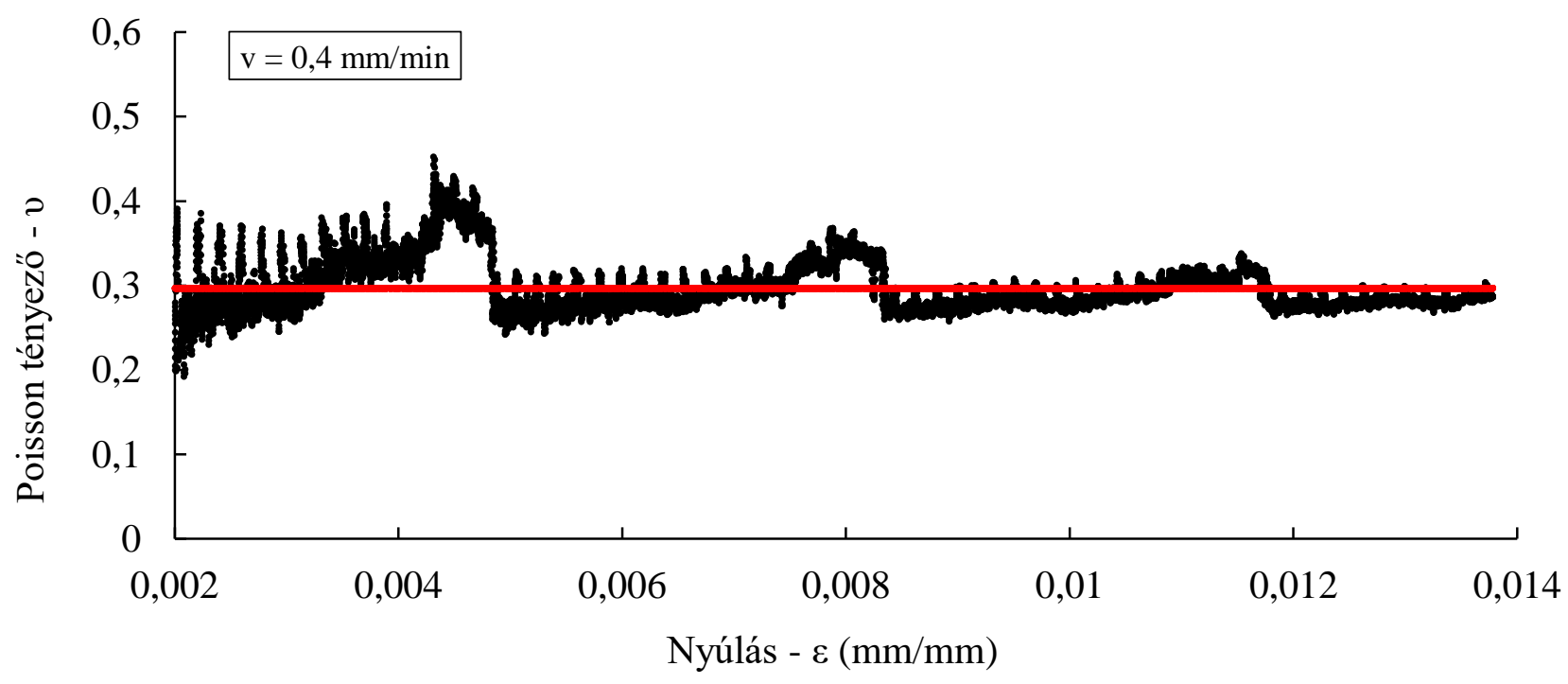

7.ábra. A Poisson tényező mért és számolt értékei az alakváltozás függvényében 
1.táblázat: A vizsgált METGLAS fémüveg szalag szakítóvizsgálati eredményei

\begin{tabular}{|c|l|l|l|l|}
\hline & $R_{m}\left[\mathrm{~N} / \mathrm{mm}^{2}\right]$ & \multicolumn{1}{|c|}{$E[\mathrm{GPa}]$} & \multicolumn{1}{|c|}{$v_{\text {mért }}$} & \multicolumn{1}{c|}{$v_{\text {számitott }}$} \\
\hline$I I v=0,4 \mathrm{~mm} / \mathrm{min}$ & 1671 & 136 & 0,36 & 0,40 \\
\hline$I I \_v=0,4 \mathrm{~mm} / \mathrm{min}$ & 2082 & 151 & 0,29 & 0,30 \\
\hline$I I I v=0,4 \mathrm{~mm} / \mathrm{min}$ & 1708 & 168 & - & 0,37 \\
\hline$I \_v=4 \mathrm{~mm} / \mathrm{min}$ & 1899 & 146 & 0,28 & 0,32 \\
\hline II_v $=4 \mathrm{~mm} / \mathrm{min}$ & 2297 & 162 & 0,48 & 0,35 \\
\hline III_v=4mm/min & 1808 & 175 & 0,50 & 0,45 \\
\hline átlag & 1911 & 156 & 0,38 & 0,37 \\
\hline szórás & 240 & 14,6 & 0,1 & 0,05 \\
\hline
\end{tabular}

A szakítóvizsgálatok eredményeit az 1. táblázatban összesítjük. Az eredményekböl látható, hogy a fémüveg szalag mechanikai tulajdonságai a hagyományos fémes anyagokhoz képest meglehetősen nagy szórással bírnak. Ez az anyag különleges mikroszerkezetéböl és kicsiny lemezvastagságából együttesen adódik. Hasonló jelenségek figyelhetők meg a szilárdság szempontjából a [7, 8, 9, 10] tanulmányokban is. A Poisson-tényezők átszámolásával viszont, amely az átlag értékben nem okozott említésre méltó változást, az egyes mérések közötti szórás egy nagyságrenddel csökkent. Mind a szilárdsági, mind pedig az alakváltozási jellemzők eredményei összevetésre kerültek a szakirodalomban található viszonylag kevés adattal [1, 7, 8, 9, 10, 11], amelyek alapján elmondható, hogy a mért eredmények más kutatásokkal összhangban vannak, illetve a vizsgált szalag Poisson-tényezőjének definiálásával, mintegy a rugalmassági állandók kiegészítése is megtörtént.

\section{Összefoglalás}

A kutatás ultravékony fémüveg szalag egytengelyű feszültségi állapotban mérhető mechanikai tulajdonságait vizsgálja, mivel az alkalmazott "METGLAS" elnevezésű anyag kapcsán igen kevés adat áll rendelkezésre a mechanikai tulajdonság részleteit illetően. A vizsgálatok két részre osztódtak. A próbatest kivágása során, mivel az lézersugaras vágási technológiával valósult meg szükségesnek bizonyult az ideális vágási paramétereknek, továbbá a vágási hőhatásnak a vizsgálata. A próbavágott élek keménységmérési és mikroszkópi vizsgálatoknak lettek e célból alávetve. A vizsgálatok során megállapításra került, hogy az ultrarövid impulzus idejü (femtoszekundumos) lézersugárral történő vágás során $40 \%$ teljesítmény és $30 \mathrm{~m} / \mathrm{s}$ pásztázási sebesség bizonyult ideálisnak. A második szakaszban, a lézersugárral vágott próbatestek szakítóvizsgálata történt meg. Mérési eredményeink alapján az anyag szakítószilárdsága átlagosan 1911 MPa-ra adódott, valamivel több mint 10\%-os szórás mellett. A rugalmas alakváltozási mérőszámok tekintetében, érintésmentes nyúlásmérő rendszerrel meghatároztuk az anyagra jellemző rugalmassági modulust (átlagosan $156 \mathrm{GPa}$ ), és ezen felül a Poisson tényező (átlagosan $0,37)$ értékét. Mindkét mérőszám érzékeny a rugalmas alakváltozás növekedésére, de nagyjából 0,01 nyúlás felett már együttesen felveszik a rájuk, nagyobb alakváltozásoknál jellemző állandó értéket.

\section{Köszönetnyilvánítás}

Köszönettel tartozom a kutatás támogatásáért, amely az „EFOP-3.6.2-16-2017-00016 Autonóm járművek dinamikája és irányítása az automatizált közlekedési rendszerek követelményeinek szinergiájában" pályázat keretében valósult meg.

\section{Irodalomjegyzék}

[1] Prohászka János: Fémek és ötvözetek mechanikai tulajdonságai. Müegyetemi Kiadó, Budapest, 2001. ISBN 9634206719 
[2] Temesi Ottó: Amorf-Nanokristályos Lágymágneses Ötvözetek, 2013

[3] Dr. Hargitai Hajnalka - Dr. Zsoldos Ibolya: Korszerủ anyagok és technológiák, Széchenyi István Egyetem, Győr, 2014. ISBN 978-615-5391-20-0

[4] https://www.liquidmetal.com, Liquidmetal, 2020.06.05

[5] MSZ EN ISO 6507-1:2018 "Fémek Vickers keménységmérés 1. rész"

[6] MSZ EN ISO 6892-1:2020 Fémek. Szakítóvizsgálat

[7] Nagy Márton és mtsai: Amorf és nanokristályos lágymágneses anyagok bevezethetőségének vizsgálata a gépjármü elektromotorok gyártásába, Kohászat 40. oldal, Országos Magyar Bányászati és Kohászati Egyesület, 2020. ISSN 0005-5670

[8] Haichao Sun és mtsai: Tensile strength reability analysis of Cu48Zr48Al4 amorphous microwires, Metals, 2016. doi:10.3390/met6120296

[9] J.J. Fan és mtsai: Reability of the plastic deformation behavior of a $\mathrm{Zr}$ - based bulk metallic glass, Intermetallics, 2016. doi:10.1016/j.intermet.2016.05.001

[10] J.J. Lewandowski - W.H. Wang - A.L. Greer: Intrinsic plasticity or brittleness of metallic glasses, Philosophical Magazine Letters, 2013. doi:10.1080/09500830500080474

[11] Metglas $®$ Magnetic Alloys Brochures: https://metglas.com/brochures/\#brochure safety, 2021. 04. 12. 